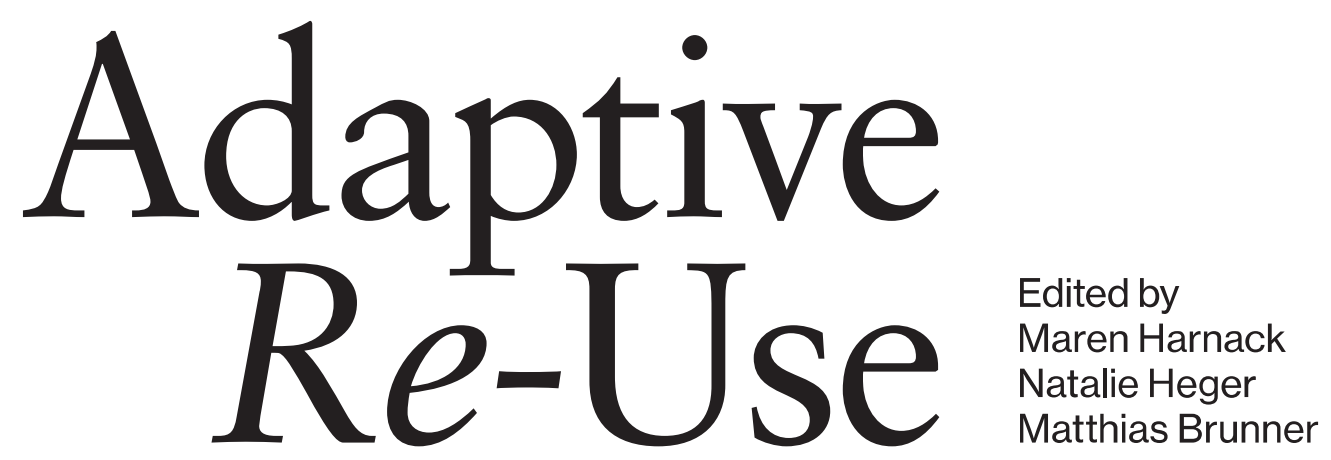

Strategies for Post-War Modernist Housing 
7 Introduction

Maren Harnack, Natalie Heger, Matthias Brunner

17 Larger_Taller_Denser

Post-War Modernist Housing

in the Stuttgart Region

Martin Hahn

27 Large-Scale Heritage

A Conservation Perspective

on Late Modernist Housing

Mark Escherich

37 Highly Visible \& Highly Valuable

Big Housing Estates of the Boom Years

Silke Langenberg

47 Multi-Storey Housing in Britain A Historical and Heritage Overview

Miles Glendinning

59 The Crux of Inward Development

Stefan Kurath, Simon Mühlebach

67 Maintenance, Repair, and Renovation of the Finnish Post-War Housing Stock

Tapani Mustonen

75 Wolfsburg

Preserving Urban Design in

Neighbourhoods Built Between

1938 and 1968

Susanne Dreissigacker, Nicole Froberg 
85 Future Prospects for the Neue Vahr An Interdisciplinary Approach to Drafting a Leitbild

Katja-Annika Pahl

95 Conservation or Replacement of Large Housing Estates? Experiences from Bijlmermeer, Amsterdam, the Netherlands

Frank Wassenberg

105 That's How It Works!

Replacing the Student Housing Complex in the Olympic Village, Munich

Natalie Heger

115 Preserving the Legacy of Álvaro Siza Teresa Cunha Ferreira, José Aguiar

127 Bremer Punkt

Serial Diversity

John Klepel

137 Authors

142 Image Credits

144 Imprint 


\title{
Preserving the Legacy of Álvaro Siza
}

\author{
Teresa Cunha Ferreira \\ José Aguiar
}

Despite its international recognition, modernist architecture in Portugal is a 'heritage at risk', since it belongs to a recent past that has not yet been sufficiently recognised in the country, either by the safeguarding organisations or by the public opinion. In fact, many buildings are threatened, both by their advanced state of degradation due to their lack of use and maintenance, and by intrusive and transformational interventions. Nevertheless, some positive initiatives have been carried out in the form of inventories, such as the 'Survey on Twentieth-Century Architecture'1 and the increasing number of conferences, exhibitions, and publications relating to the country's modernist architectural heritage. Additionally, the number of listed buildings from the last century has been growing in recent years, including a large number of modernist and post-war buildings: 201 properties in total, including six National Monuments, 149 Buildings of Public Interest (regional level), and 46 buildings of Municipal Interest (local level). Moreover, an 'Ensemble of Álvaro Siza's Architecture Works in Portugal'2 (18 works, from 1956 to 2006) was included by the Portuguese Government in the World Heritage Tentative List (2017), in response to the Global Strategy of the UNESCO World Heritage Committee encouraging State Parties to submit nominations for twentieth-century heritage. ${ }^{3}$

1 'IAP20', www.iap20.pt (last accessed 2 April 2020).

2 This proposal was submitted on 3 I January 2017 , at the suggestion of ICOMOS-Portugal, by the Permanent Delegation of Portugal to UNESCO under the Cultural Heritage criteria (i), (ii) and (iv), see 'Ensemble of Álvaro Siza's Architecture Works in Portugal', https://whc.unesco.org/en/ tentativelists/6224/ (last accessed 2 April 2020).

3 Jukka Jokilehto, Henry Cleere, Susan Denyer, and Michael Petzet, eds., The World Heritage List: Filling the Gaps an Action Plan for the Future, Monuments and Sites I 2 (Paris: ICOMOS, 2005). 
Preserving the Legacy of Álvaro Siza

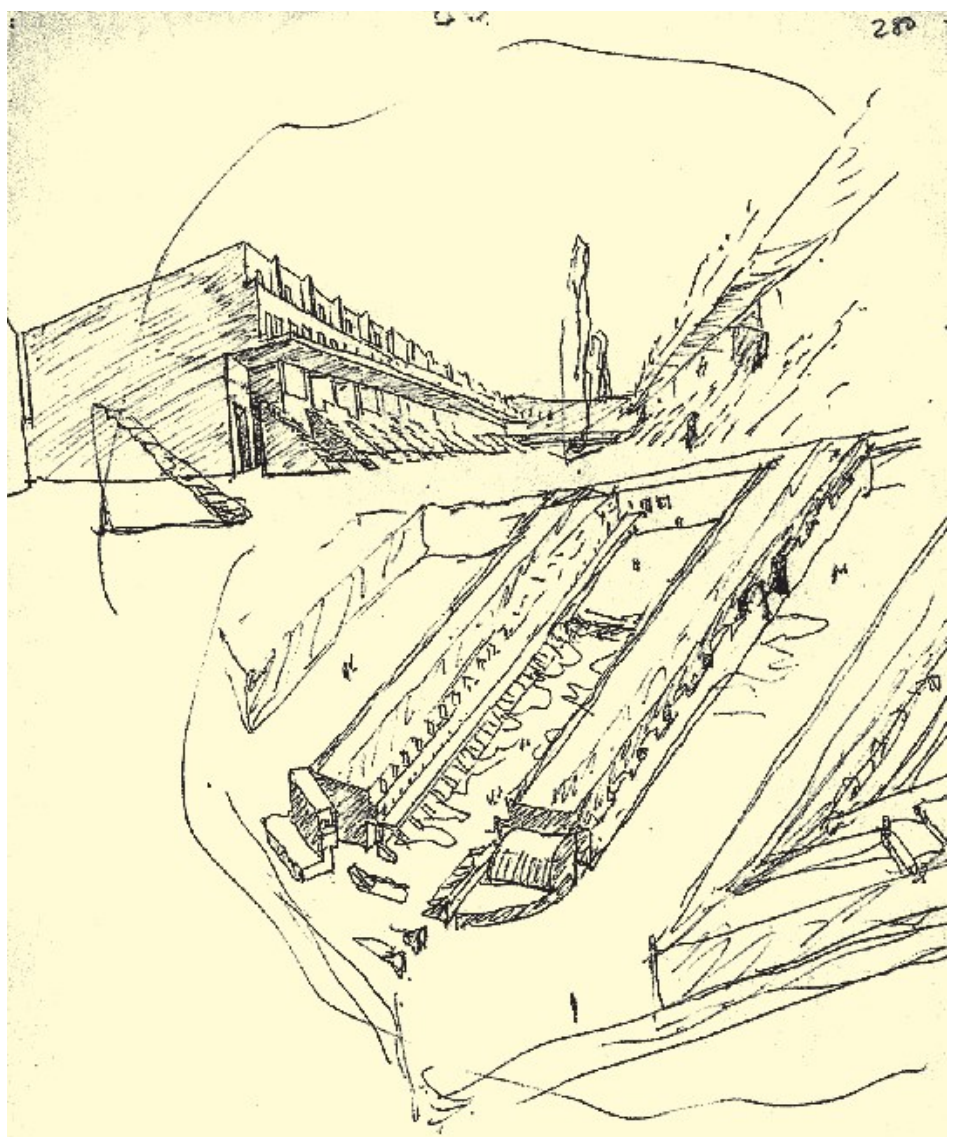

1 Sketch by Álvaro Siza, 1974.

\section{The Siza Way of Preservation}

In recent years, Álvaro Siza has been heavily committed to the preservation of some of his own early works, including the Boa Nova Tea House and Restaurant (1958-63; 1992; 2012-14), the Bouça Housing Complex (1975-78; 2000-06), the Faculty of Architecture of the University of Porto (1985-92; 2016-18), the Swimming Pool at Quinta da Conceição (1958-65; 2016-18), and, more recently, the Swimming Pool in Leça (1960-66; 2019-20).

4 Álvaro Siza, 'Conferencia para el $\mathrm{CAH}_{2}$ ', in Intervention Approaches in the 2oth Century Architectural Heritage: International Conference

The conservation of the Boa Nova Tea House and Restaurant in 1992 was his first intervention on a former work and, in his own words, was an important experience for his following works on pre-existing buildings. ${ }^{4} \mathrm{After}$ his first intention of making changes to the original design (designed by a much younger

CAHzothC. Madrid Document 20II, edited by J. M. Hernández León and F. Espinosa De Los Monteros (Madrid: Ministerio de Educación, Cultura y Deporte, 20II), p. I86. 


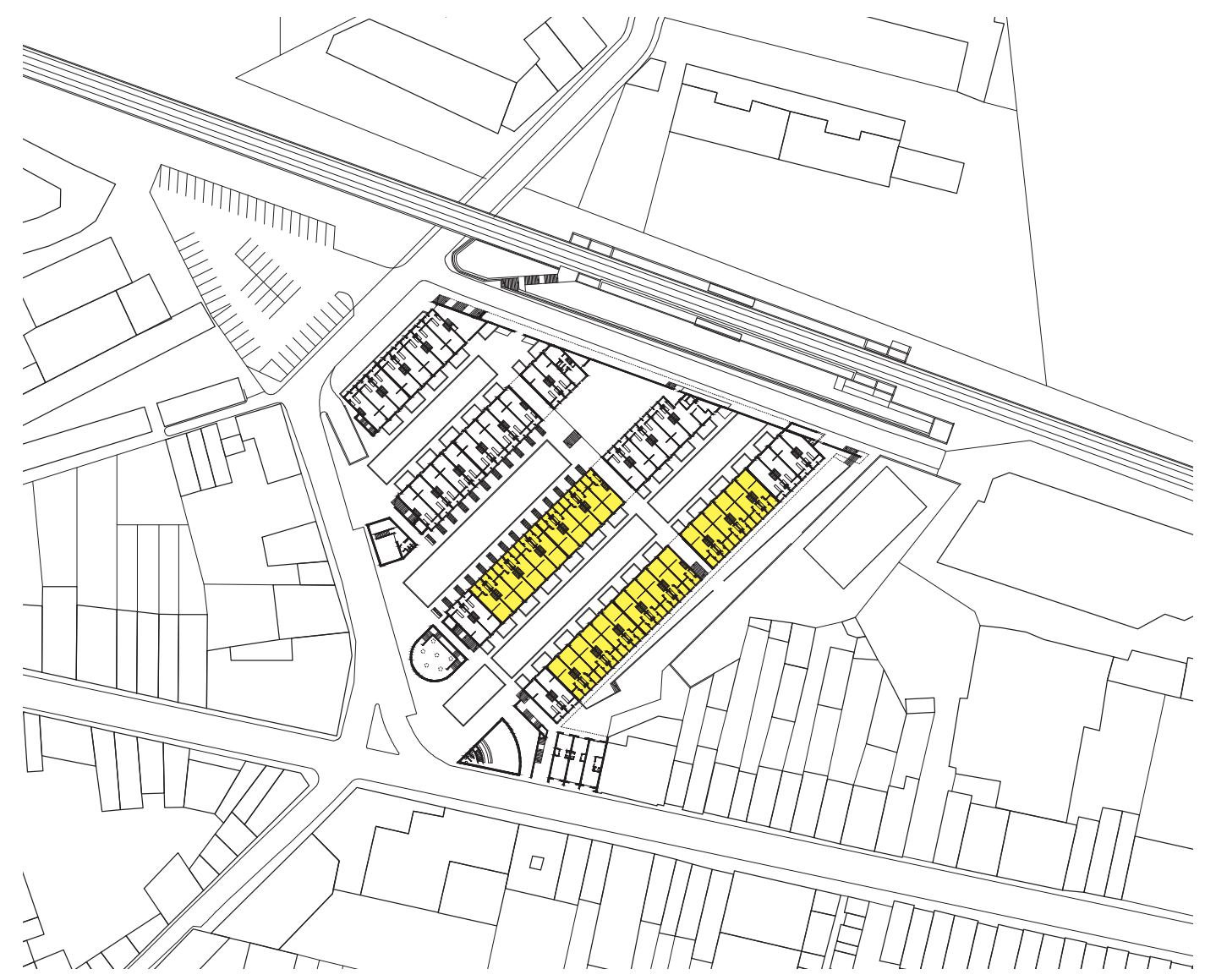

2 General plan with phase I in yellow, I973-78.

self), Siza was then able to recognise the building's value and coherence as a whole. He thus resisted the temptation to correct his own work, and decided to maintain the original design, arguing that 'in a rehabilitation there is a mandatory requirement, which is [...] absolute integrity. No changes should be performed 5 Ibid., pp. I 86-88.

[...] unless extremely necessary'.5

In 2012, twenty years after his first conservation of the Boa Nova Tea House and restaurant, Siza was called on to perform a second intervention for the preservation of the building after it had been abandoned and vandalised. In these recent works, Siza preserved or reproduced all the exterior and interior features, with the exception of updating the services (toilets and kitchens) and technical infrastructures. Additionally, because of the maritime location, the property required repairs to the concrete as a result of spalling and cracking caused by 

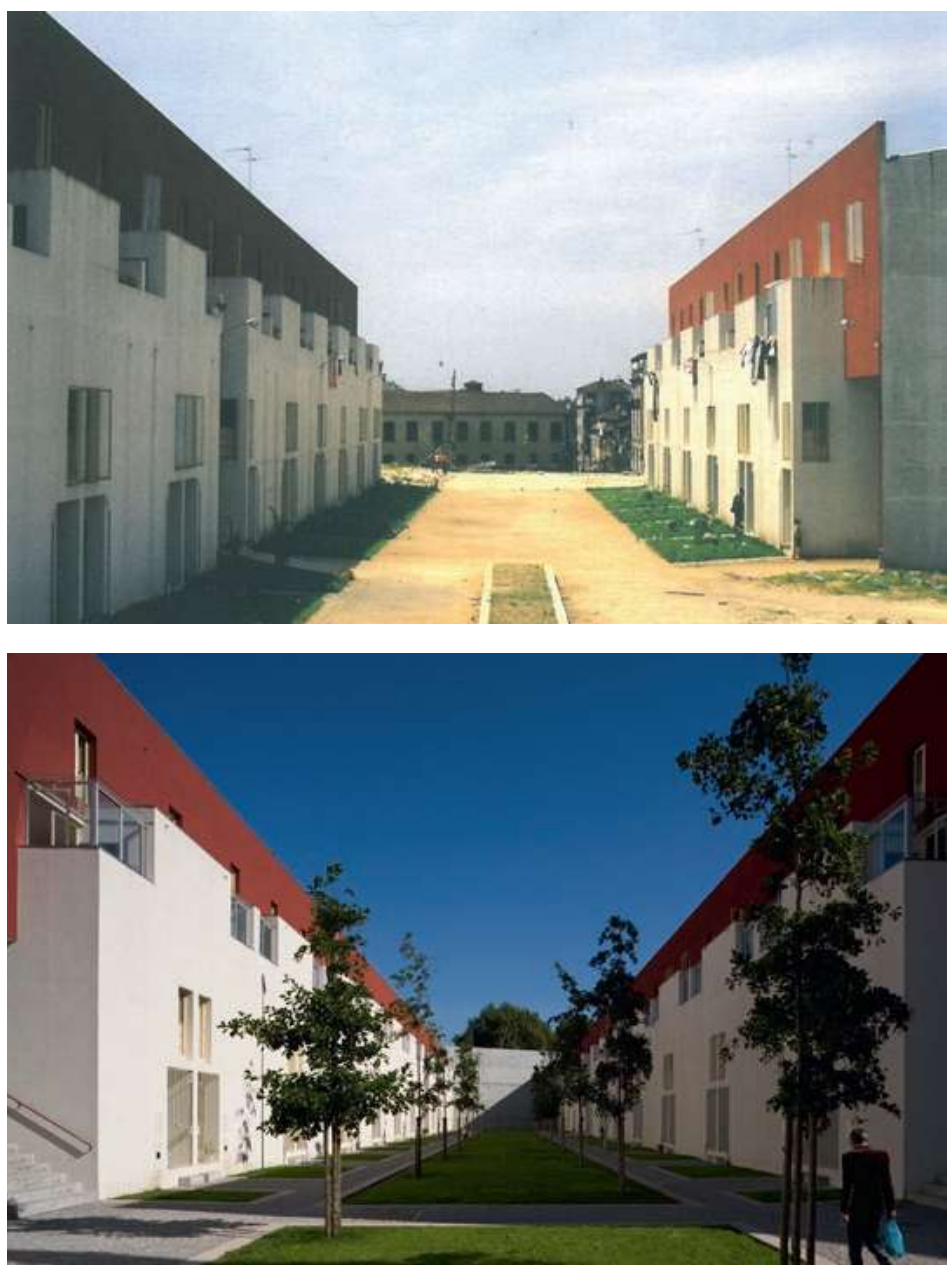

3 Exterior views of phase I and phase II (photos ca. I979 and today).

corrosion of the reinforcement steel. The repairs consisted of anti-corrosion treatment, protective painting, and the application of a new cement mortar coating with a similar texture to the original one. ${ }^{6}$ According to Siza, this is one of the most challenging issues in the conservation of modernist architecture, because localised repairs are necessarily visible. Nevertheless, in his opinion, they are preferable to integral replacement of existing concrete. For this reason, he defends 'minimum intervention because it's not desirable and it wouldn't be possible to hide what is determined by the passage of time'. ${ }^{7}$

6 Samples were tested (with the Secil company) to ensure that the final solution was technically and aesthetically compatible with the original work. Ibid., p. 7 .

7 Ibid.

8 José António Bandeirinha, $O$ Processo SAAL e a Arquitectura no 25 de Abril de 1974 (Coimbra: Imprensa da Universidade, 2007). See also Alexandre Alves Costa, 'L'esperienza di Oporto', Lotus International, no. I8 (1978), pp. 66-70. 


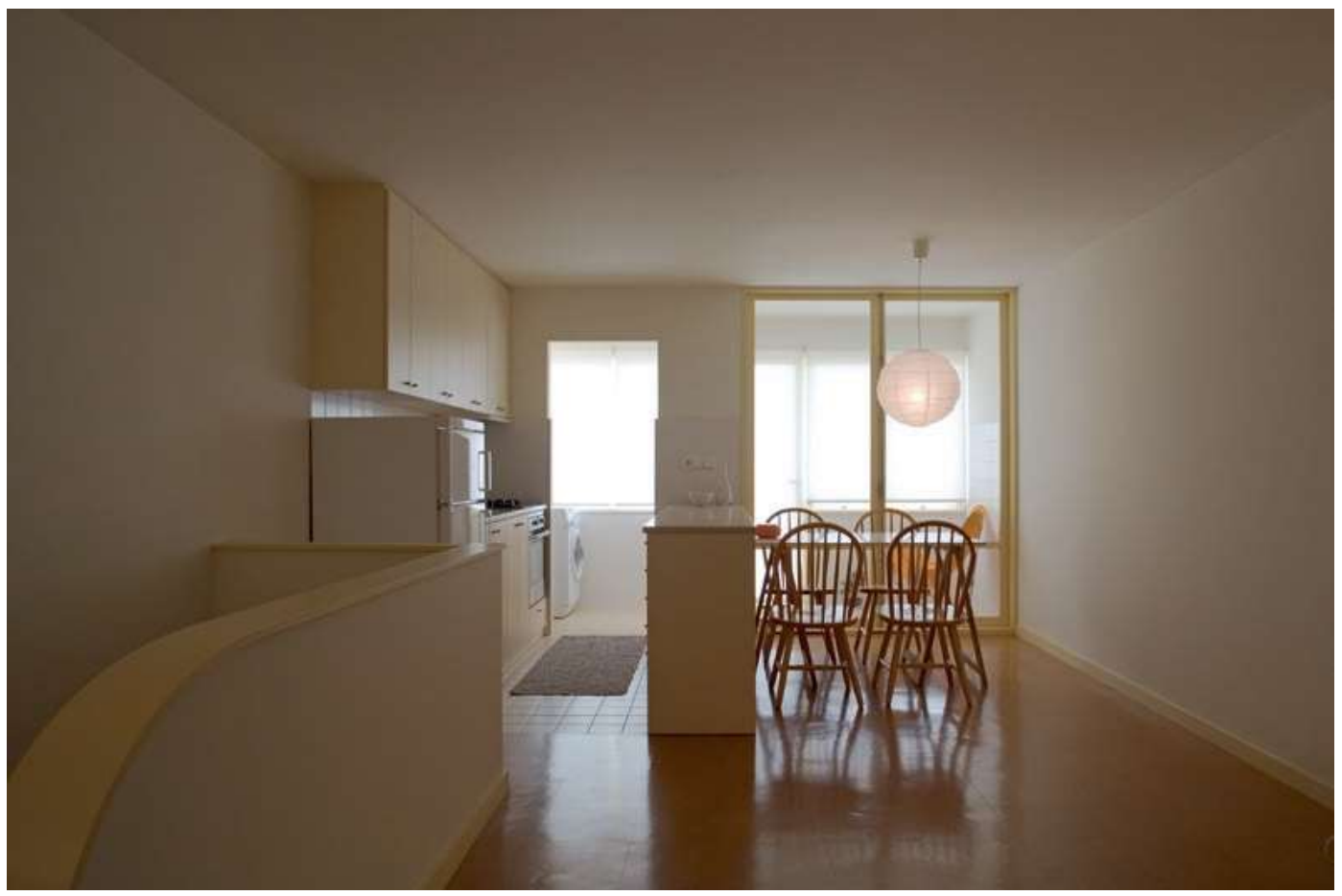

4 Interior view of phase II.

\section{Adaptive Re-Use of the Bouça Housing Complex}

Since the 1970s, social housing has been one of the most prominent areas of Alvaro Siza's work, allowing him to move from the scale of the building to that of the city. Siza was particularly committed to the SAAL process (Local Ambulatory Support Service) - the government-funded programme for rehousing slum-dwellers implemented after the democratic revolution of 1974 - seeking to solve the precarious housing conditions of central Porto's working-class neighbourhoods (the so-called 'ilhas'). The creation of SAAL in 1974 took place at a unique moment in the history of Portugal, in which participatory processes were tested in a close relationship between the designers (the brigades) and the population. ${ }^{8}$ Siza's housing projects of São Victor (1974-77) and Bouça (1973-78), and later at Malagueira in Évora (launched in 1977) were inspired by inter-war modernist housing schemes with sympathetic adaptation to the specific context. ${ }^{9}$

9 Namely Kiefhoek Housing Estate by J. J. Pieter Oud in the Netherlands (1925-29), Onkel Toms Hütte (I926-3I) and the Carl Legien Housing Estate (1928-30) by Bruno Taut in Germany. See Wilfred Wang, 'Bouça and Public Housing at the Beginning of the 2ist Century', in Bouça Residents Association Housing, O’Neil Ford Monograph I, edited by Wilfred Wang and Brigitte Fleck (Austin: Center for American Architecture and Design, 2008), p. 65. 
Although the Bouça Housing Complex was formally commissioned by the Fundo Fomento da Habitação (Housing Development Fund) in 1973, the first sketches are from $1972 .{ }^{10}$ The first phase (56 dwellings) was designed in 1973-75, and it was fully completed and occupied by 1978. However, the construction process was interrupted (following the disbandment of SAAL in October 1976), and the second phase (74 dwellings) would only be completed thirty years later (2000-06).

The Bouça Complex consists of four parallel but discontinuous lines of three or four-storey housing blocks, arranged in linear rows forming four narrow courtyards. The southern end of each line originally housed the community facilities (the laundry, the library, and the meeting spaces used as the association's headquarters). These have been recently converted into new functions. On the northern border of the complex, a concrete wall was built as a noise-dampening barrier as well as for providing access to the new metro station. ${ }^{11}$ The dwellings' areas range from 75 to 80 square metres - a luxury for the early residents - and the units have a width of four metres. ${ }^{12}$ They are organised over two floors, dividing a more 'social' area with living-dining-kitchen area and a small loggia on the lower floor, and bedrooms and bathroom on the upper floor.

Situated in a central area of Porto, which is now under pressure from the property market and tourism, Bouça remained a post-revolutionary eyesore for almost twenty-five years, until Siza was commissioned to plan the missing buildings and to rehabilitate the existing ones. Although this recent addition was based on the original design project ${ }^{13}$ in terms of its areas and construction systems, the original residents from the 1974 slums had already been relocated to other urban areas, and an upper middle-class population was to purchase the new or renovated houses. In Siza's own words, this gentrification process created a 'mismatch between the type of housing and its user,' as it became a posh residential location for aspiring young people with a high incidence of architects. ${ }^{14}$

Nevertheless, according to Siza, the recent project (2000-06; in association with António Madureira) followed the initial design with minor changes, and benefited from the $\mathrm{Mu}-$ nicipal Council understanding the impossibility of meeting all the present regulations for new housing complexes. As in the initial project, there was a dialogue between Siza and the residents, who presented some ideas such as security bars on the

10 Ibid., p. 28.

11 See the text and drawings preserved at the Drawing Matter Archive, Somerset, UK:

'Saal Bouça Housing, Porto, by Álvaro Siza (1972-73; I974-79; 2004-07)', https:// www.drawingmatter.org/ drawings/gowan-and-sizahousing-and-city/saalbou $\mathrm{C}_{3} \% \mathrm{~A}_{7}$-housing-porto/ (last accessed I4 March 2020).

12 The width of four metres relates directly to the $i l h a$ house. However, instead of the four by four metres that usually constituted the minimum housing cell in an ilha, in Bouça the dimensions expand in depth (twelve metres) and in height (two floors). Clara Pimenta do Vale, 'The Social Rise of a Housing Intervention: Álvaro Siza Project for Bouça Neighbourhood' (conference paper, 42nd IAHS World Congress, the housing for the dignity of mankind, Naples, 2018), p. 5. 13 Álvaro Siza, Interview with Teresa Cunha Ferreira on I4 January, 2018 (unpublished). 14 Ibid. 


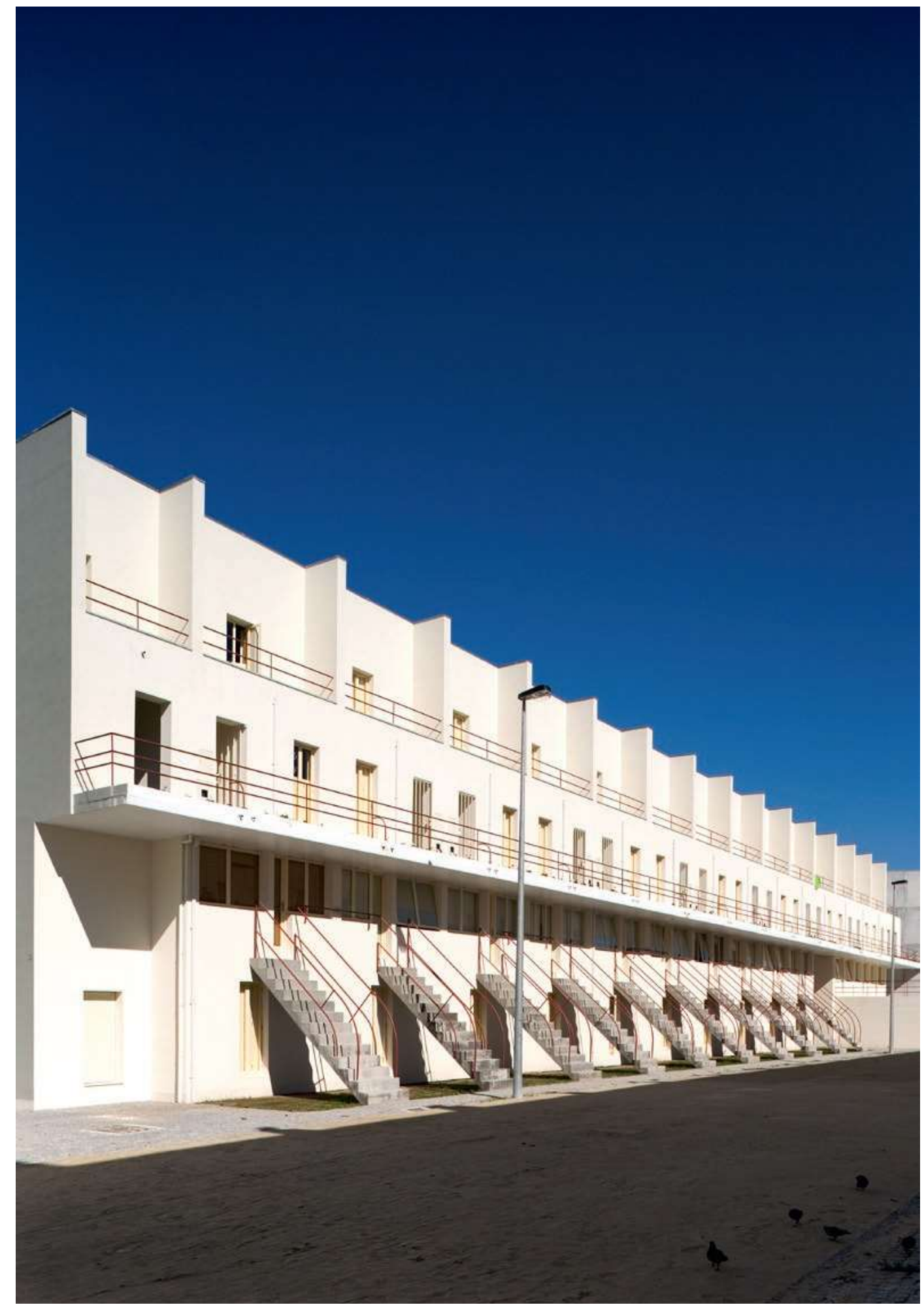

5 Exterior view of phase II. 
Preserving the Legacy of Álvaro Siza

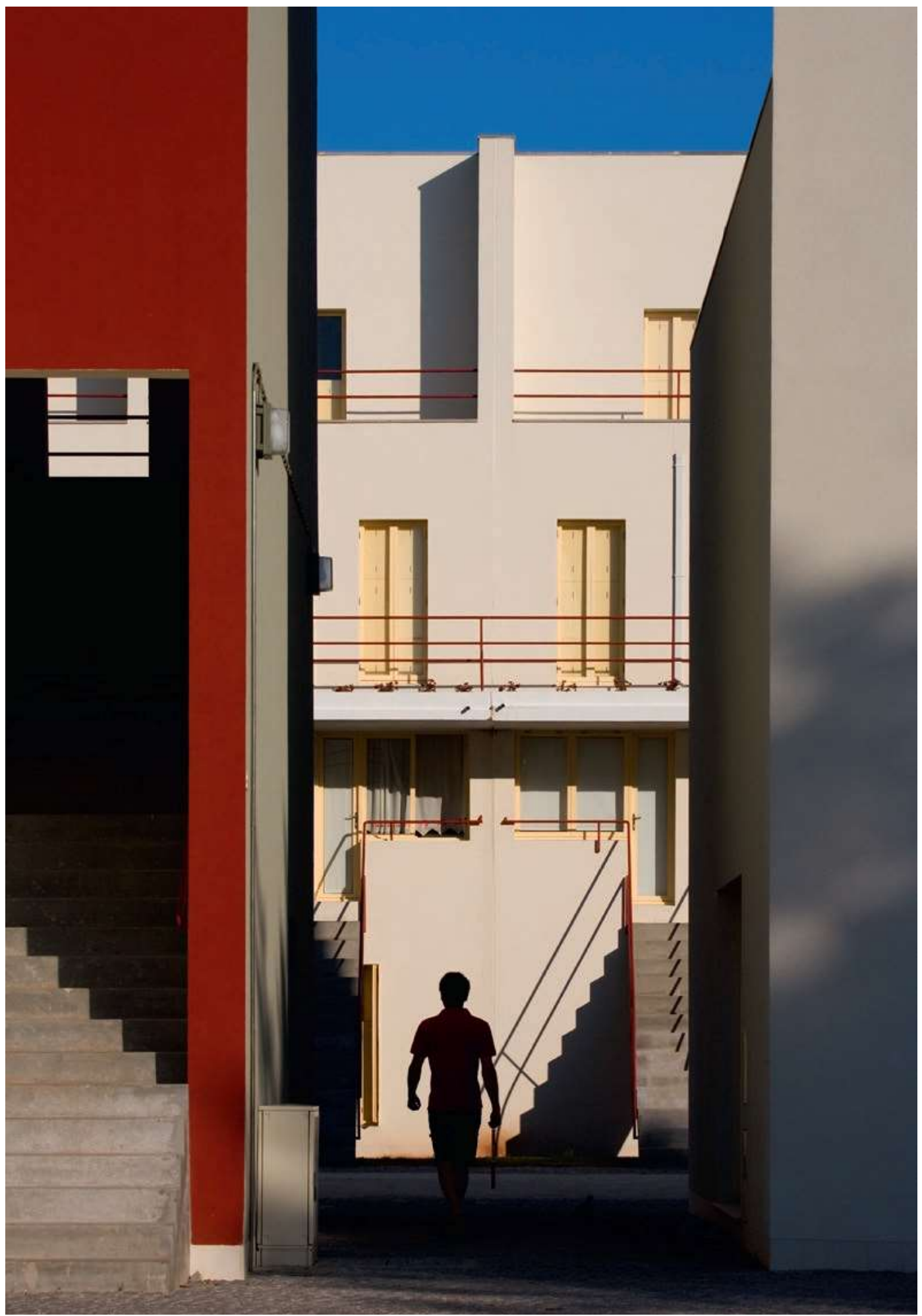

6 Exterior view of phase II. 
ground floor windows and closed balconies on the upper floors. ${ }^{15} 15 \mathrm{Ibid}$

Also, small updates were made in the dwellings: the social area is now more open, with the kitchen part of the living room, a sliding door between the dining area and the living room serves to increase functional flexibility, the WC is separated from the bathroom, and the size of the winter gardens is reduced. ${ }^{16}$ Moreover, underground parking was added to accommodate the increased number of private cars.

These updates to the original design also took into account new construction technologies (concrete blocks were replaced by reinforced concrete sheets), as well as current standards of comfort and energy consumption. ${ }^{17}$ While the interior finishes and the window frames were made from materials identical to the original ones, the exterior coatings were modified to improve thermal performance, through the use of the External Thermal Insulation Composite System (ETICS) in the façades. ${ }^{18}$ Although the use of ETICS may change the modernist morphology and aesthetics profoundly, in this case Siza managed to reduce its impact on the building's appearance.

We can conclude that this recent project retains the typological characteristics and the internal organisation of the houses, specifically in terms of access, interior circulation, and the relationship between the kitchen and the common areas. These constitute an outstanding characteristic of the design and are one reason why La Bouça is still discussed within the context of national and international post-war architecture. ${ }^{19}$ From an early stage, this work was considered a masterpiece by renowned international and national architectural critics, and it is now listed in the Heritage Map of the Municipal Masterplan of Porto, as well as in other national inventories such as SIPA, ${ }^{20}$ IAP2O, ${ }^{21}$ and the World Heritage Tentative List. ${ }^{22}$

\section{Final Remarks}

This paper has focused on the survival of post-war architecture, Lesson of Álvaro Siza', in Metaand, in particular, on the legacy of Alvaro Siza and his contribu- Change, Proceedings of the tions to the design and preservation of his own post-war mod- $15^{\text {th }}$ International Docomomo ernist housing. Having been heavily committed in recent years to working on the built heritage, including several of his own projects, ${ }^{23}$ Siza maintains that in 'conservation there is a com- pp. $338-44$.

16 Wang, 'Bouça and Public Housing at the Beginning of the 2Ist Century' (above, n. 9), p. 69.

17 Pimenta do Vale, 'The Social Rise of a Housing Intervention' (above, n. I2), p. ro.

18 Ibid., p. II.

19 Nuno Grande and Roberto

Cremascoli, eds., Neighbour-

hood: Where Alvaro Meets Aldo

(Berlin: Hatje Cantz, 20I7).

20 Patrimonio Cultural, 'Bairro

da Bouça / Bairro SAAL da

Bouça / Conjunto Habitacional da Bouça-IPA.00025032',

http://www.monumentos.gov. $\mathrm{pt} /$ site/app_pagesuser/SIPA. aspx?id=25032 (last accessed 2 April 2020).

21 IAP2O, 'n ${ }^{\circ}$ I00223', http:// www.iap2o.pt/Site/FrontOffice/ default.aspx (last accessed 2 April 2020).

22 Permanent Delegation of Portugal to UNESCO, 'Ensemble of Álvaro Siza's Architecture Works in Portugal' (above, n. 2).

23 Teresa Cunha Ferreira, 'Conservation of 2oth-Century Architecture in Portugal: The Conference, edited by Ana Tostões and Nataša Koselj (Ljubljana: Docomomo, 2018), pulsory requirement, which is [...] absolute integrity. No changes 
should be performed except [...] in special or exceptional cases, ${ }^{24}$ resisting the tendency to leave the architect's signature on a project. 25

In the case of the Boa Nova Tea House and Restaurant, Siza undertook only a minimum intervention; at the Bouça Housing Complex, however, he understood the need to include functional and technical updates in order to respond to contemporary needs and expectations (the same updates are considered in the construction of the second phase, thirty years after the original design). And yet, in both cases, although technical infrastructure and service areas were updated, the original design principles were respected.

The inclusion of an Ensemble of Alvaro Siza's works in UNESCO Tentative List for the World Heritage will have an important role in the preservation of his works in Portugal; specifically, by increasing its safeguarding and conservation planning, as well as by providing for specific governmental funding for knowledge and research on Álvaro Siza's Architecture. ${ }^{26}$ However, this first serial nomination of a living architect will also be both a challenge and an opportunity to discuss the conservation of post-war architecture, at a national and international level. From this brief analysis of Siza's contributions, we may conclude that he has been providing paradigmatic models for architectural preservation by respecting the building's integrity and significance, together with a high-quality architectural design. Thus, as Álvaro Siza maintains: 'architects do not invent anything; they transform reality. ${ }^{27}$
24 Siza, 'Conferencia para el $\mathrm{CAH}_{2}$ ' (above, n. 4), p. I 88. 25 Álvaro Siza, Recuperaçãoe Manutenção: A intervenção no património: Práticas de conservação e reabilitação (Porto: FEUP, 2005), p. 2 I.

26 See, among other initiatives: FCT, 'Scientific Research and Technological Development Projects in the Scope of Álvaro Siza Vieira Architecture 2019', https:// www.fct.pt/apoios/projectos/ concursos/sizavieira/index. phtml.en (last accessed 2 April 2020).

27 Álvaro Siza, Architecture Writings, ed. Antonio Angelillo (Milan: Skira, I997), p. 34.

The authors acknowledge Alvaro Siza, Wilfred Wang, Fernando Guerra and Brigitte Fleck for the image credits. Drawings and Photographs published in Wilfred Wang and Brigitte Fleck (eds.), Bouça Residents Association Housing (Austin: The Center for American Architecture and Design; O'Neil Ford Monograph, 2008). Assignment co-financed by the European Regional Development Fund (ERDF) through the COMPETE 2020-Operational Programme Competitiveness and Internationalization (POCI) and national Portuguese national funds by from the FCT under the POCI-01-0145-FEDER-007744 project. 
Illustration Credits

\begin{tabular}{|c|c|}
\hline Cover & Ben Kuhlmann \\
\hline p. 9 & Malte Sänger \\
\hline p. 11 & Ben Kuhlmann \\
\hline p. 13 & Ben Kuhlmann \\
\hline p. 18-19 & Karin Hopfner, HfT Stuttgart \\
\hline p. 21 & Martin Hahn, LAD BW \\
\hline p. 22 & Simone Meyder, LAD BW \\
\hline p. 23 & O. Braasch, LAD BW \\
\hline p. 30 & LDA Thüringen \\
\hline p. 31 & LDA Berlin \\
\hline p. 32 & Mark Escherich \\
\hline p. 33 & Mark Escherich \\
\hline p. 34 & Martin Maleschka \\
\hline p. 35 & Peter Writschan \\
\hline p. 38 & Archiv Neue Heimat \\
\hline p. 39 & Christian Zocher \\
\hline p. 40 & Hinteregger factory \\
\hline p. 43 & Tania Reinicke und Ekkehart Bussenius \\
\hline p. $48-52$ & Miles Glendinning \\
\hline p. 60 & $\begin{array}{l}\text { Michael Wolgensinger, Baugeschichtliches } \\
\text { Archiv der Stadt Zürich, } 1953\end{array}$ \\
\hline p. 61 & $\begin{array}{l}\text { Grafic: IUL, ZHAW, 2019, data basis: Bundesamt } \\
\text { für Statistik }\end{array}$ \\
\hline p. 64 & IUL, ZHAW, 2014 \\
\hline p. 65 & IUL, ZHAW, 2017 \\
\hline p. 70 & $\begin{array}{l}\text { Tapani Mustonen, Architects Mustonen Ltd, } \\
\text { Helsinki }\end{array}$ \\
\hline p. 71 & $\begin{array}{l}\text { Tapani Mustonen, Architects Mustonen Ltd, } \\
\text { Helsinki }\end{array}$ \\
\hline p. 76 & $\begin{array}{l}\text { Photographer unknown, source: Institut für } \\
\text { Zeitgeschichte und Stadtpräsentation }\end{array}$ \\
\hline p. 77 & Lars Landmann \\
\hline p. 78 & $\begin{array}{l}\text { Photographer unknown, source: Untere Denk- } \\
\text { malschutzbehörde }\end{array}$ \\
\hline p. 79 & Lars Landmann \\
\hline p. 80 & $\begin{array}{l}\text { Photographer unknown, source: Institut für } \\
\text { Zeitgeschichte und Stadtpräsentation }\end{array}$ \\
\hline p. 81 & Lars Landmann \\
\hline p. 86 & $\begin{array}{l}\text { Source: Hamburgisches Architekturarchiv, } \\
\text { Bildarchiv der Neuen Heimat }\end{array}$ \\
\hline p. 87 & Frank Heinrich Müller, photographiedepot.de \\
\hline p. 88 & Katja-Annika Pahl \\
\hline
\end{tabular}


p. 89 AGUS, bgmr, COBE Berlin

p. 90 AGUS, bgmr, COBE Berlin

p. 96 Source: (top) Municipal prospect, 1968, Amsterdam, (bottom) Beeldbank Stadsarchief Amsterdam

p. 99 Frank Wassenberg

p. 100-101 Source: Projectbureau Vernieuwing Bijlmermeer, in: Wassenberg, 2013, p. 179, circle added by the author

p.102 Henno Eggenkamp, Bijlmer Museum

p.106 Natalie Heger

p. 107 Silvie Tillard

p. 108 Werner Wirsing

p.109 Natalie Heger

p.110 Arge bogevischs buero architekten \& stadtplaner $\mathrm{GmbH}$ and Professor Werner Wirsing

p.111 Natalie Heger

p. 116 Alvaro Siza, 1974

p. 117 Forschungslabor Baukultur und Siedlungsbau der Nachkriegsmoderne

p.118 (top) Birgitt Fleck 1979, (bottom) Fernando Guerra

p. 119-122 Fernando Guerra

p. 128-131 LIN Architekten Urbanisten

p. 132-133 Nikolai Wolff

p. 134 GEWOBAG 
Imprint

(c) 2020 by jovis Verlag $\mathrm{GmbH}$

Texts by kind permission of the authors.

Pictures by kind permission of the photographers/holders of the picture rights.

All rights reserved.

Cover: Hirschsprung housing estate, Dreieich-Sprendlingen, 1956-63, photo Ben Kuhlmann.

Design and setting: Felix Holler (Stoffers Grafik Design, Leipzig) Lithography: Torge Stoffers, Stefan Rolle (Stoffers Grafik Design, Leipzig) Printed in the European Union

Bibliographic information published by the Deutsche Nationalbibliothek The Deutsche Nationalbibliothek lists this publication in the Deutsche Nationalbibliografie; detailed bibliographic data are available on the Internet at http://dnb.d-nb.de

Forschungslabor Baukultur und Siedlungsbau der Nachkriegsmoderne at the Frankfurt University of Applied Sciences www.frankfurt-university.de/nachkriegsmoderne

Jovis Verlag GmbH

Lützowstrasse 33

10785 Berlin

www.jovis.de

jovis books are available worldwide in select bookstores. Please contact your nearest bookseller or visit www.jovis.de for information concerning your local distribution.

ISBN 978-3-86859-611-3 